\title{
Impact of SMEs Green Supply Chain Practice Adoption on SMEs Firm and Environmental Performance
}

\author{
Mukesh Kumar Mishra1, Dibyendu Choudhury ${ }^{2}$, K. S. Venu Gopal Rao ${ }^{1}$ \\ ${ }^{1}$ Marketing \& Strategy, IBS Hyderabad (The ICFAI Foundation for Higher Education), Hyderabad, India \\ ${ }^{2}$ National Institute for Micro, Small and Medium Enterprises, Hyderabad, India \\ Email: mukesh26672@gmail.com, dibchoudhury@gmail.com, ksvg.rao@gmail.com
}

How to cite this paper: Mishra, M.K., Choudhury, D. and Rao, K.S.V.G. (2019) Impact of SMEs Green Supply Chain Practice Adoption on SMEs Firm and Environmental Performance. Theoretical Economics Letters, 9, 1901-1919.

https://doi.org/10.4236/tel.2019.96121

Received: June 25, 2019

Accepted: August 17, 2019

Published: August 20, 2019

Copyright (c) 2019 by author(s) and Scientific Research Publishing Inc. This work is licensed under the Creative Commons Attribution International License (CC BY 4.0).

http://creativecommons.org/licenses/by/4.0/

\section{Open Access}

\begin{abstract}
The objective of this paper is to examine the impact of SMEs green supply chain practice adoption on SMEs firm and environmental performance. This study used data from owners/managers from different Industry Associations and clusters in the SMEs domain in South India and used a two-step approach for data analysis. In the first step, a measurement model was used to assess the validity and reliability of the measures, then in the second step structural model was used to test the proposed hypotheses. The results indicate that green purchasing impacts on SMEs firm performance and environmental performance, and eco design impacts on SMEs firm performance. To author's knowledge, this paper is unique in the terms of finding impacts of green purchasing and Eco design on SMEs firm performance and environmental performance.
\end{abstract}

\section{Keywords}

Green Purchasing, Eco Design, SMEs Firm Performance, Environmental Performance

\section{Introduction}

Environmental issues and the inclusion of green practices within the supply chain is a topic that has gained importance in academic literature. This interest is mirrored by the growing interest shown by Governments and Enterprises around the world about environment and climate change and the adverse impact arising out of mismanagement resulting in adverse impact [1].

Small- and medium-sized enterprises (SMEs) are responsible for a significant 
portion of environmental pollution globally [2] but the manner in which they manage environmental issues and subsequent impact such decisions have on environment aren't well understood [3] [4] [5]). Negative environmental impact is particularly seen in manufacturing supply chains because inbound, outbound and reverse supply combine with several internal enterprise operations that emit substantial environmental pollution [6] [7] [8]). These pollution issues have local, national and international repercussions, notably in developing nations where regulations are fewer and social control less effective [9]; Ling and [10] [11]). These problems are compounded by increased global competition for markets where customer needs are met by products and services that are not only innovative but also environmentally sound [12] [13] [14]). These imperatives have led to a focus on creating "green supply chains" in which enterprises adopt practices that minimize environmental harm [15] [16] [17])

As indicated by Sarkis (2003) [18], the reconciliation of ecological issues and Supply Chain Management (SCM) has turned into a flourishing subfield in the course of recent decades. Green Supply Chain Management (GSCM) is a significant and vital goal for the enterprises that try to understand the various advantages from such works, including cost savings, more grounded brand acknowledgment and competitor' differentiation [19] [20] [21] [22] [23].

A central a part of GSCM is that the selection of "green" suppliers and suppliers' disposition to contribute towards GSCM [24] has so far received restricted comprehensive theoretical and empirical attention in a single study, despite many frameworks emphasizing the role of GSCM in achieving sustainable supply chain (SC) management practices [25].

GSCM has additionally begun to realize popularity in emerging economies like China and other Asian countries. For example, Eltayeb et al. [26] studied the outcomes of green supply chain initiatives among ISO 14001 certified enterprises in Asian nations, while Zailani et al. [27], conducted a study on GSCM research in Malaysia to assess the impact of internal and external forces on environmental performance. However, studies within the context of other emerging economy countries are still comparatively rare.

Although most enterprises acknowledge the importance of "greening" their supply chains, there are completely different approaches to the current issue [28] [29]. Two main approaches are studied within the literature: monitoring and collaboration [30]. While monitoring is based on practices like receiving supplier questionnaires and auditing, collaboration depends on additional proactive approaches like provider training and joint development of environmentally friendly processes or product [26] [31].

In a number of the earlier studies on the subject, Lamming and Hampson [32] noted that GSCM isn't solely regarding managing risks-together with client boycotts and negative media attention-however additionally concerning realizing opportunities that may add value to enterprise, together with cost efficiencies and brand differentiation and more recent work has supported such obser- 
vations [33] [34] for instance, Rao and Holt [35] found that GSCM ends up in bigger levels of competitiveness and economic performance. As such, GSCM performance is an indicator of the degree to which sustainable practices are embedded among enterprise and across the Supply Chain.

As per the Green et al. [36], the implementation of GSCM practices is expected to result in improved environmental performance as measured by reductions in air emissions, effluent waste, solid waste, and also the consumption of toxic materials. There's a concern, however, whether or not such environmental sustainability efforts can ultimately translate into improved market share and profitability. Ultimately, manufacturing managers are accountable for the performance of the enterprises that they work [37]. So, the purpose of this study is to find the impact of adoption of green supply chain to firm and environmental performance. This paper is unique in the term of finding impact of green supply chain on SMEs firm performance, earlier research has found the impact of green supply chain adoption on overall economic performance.

The article is organized as follow-introduction to green supply chain adoption, Green purchasing, eco design practice, SMEs and Green supply chain adoption, Hypothesis Development, Research Methodology, Data Analysis and Results, Discussion and managerial application, Limitations and Future Scope of Study.

\section{Green Supply Chain Practice Adoption}

GSCM is the integration of environmental thinking into supply chain, which incorporates manufacturing process, material sourcing and selection, product design and delivery of the ultimate product to the customers, in addition, a end-of-life management of the product after it helpful life [38].

GSCM is contemplated as "closing the loop" because it ranges from green purchasing to integrated SC ranging from provider, to manufacturer, to client and reverse logistics [39].

Several definitions exist within the GSCM literature [40]. Gilbert [41] explained that GSCM is integration of environmental thinking into SCM. Srivastava [36] went on to define GSCM as adding the "green" element to SC. Zhu and Sarkis [42] clarified that GSCM covers all phases of a product's life cycle from design, production and distribution phases to the utilization of merchandise by the top users and its disposal at the end of product's life cycle. GSCM is an approach for rising performance of the processes and merchandise in keeping with the requirements of the environmental laws [43].

Within the context of GSCM, actors within the supply chain operate in a way that fulfills customer and legal necessities. Given these compulsions, pressure from government agencies and national/international regulators can influence the adoption of environmentally responsible behavior [25] [44] [45]. Narasimhan and Carter [46] found that enterprises had institutionalized environmental practices because of pressure from external and internal forces additionally as an 
outcome of awareness arising from non-compliance with environmental imperatives. If enterprises have a legitimate concern for the environment and there's social approval, then environmental practices are deployed earlier throughout the supply chain (Carter et al., 2000) [47]. There exist studies that were administrated in developed countries that show the manner in which enterprises were been driven by institutional norms to boost competitive advantage by adopting environmental practices. These organizations deployed GSCM based activities that embrace training, environmental information sharing and joint research.

According to Heras-Saizarbitoria et al. [48] and Vachon [49], external motivators and particularly, customer pressure are key drivers of the adoption of ISO 14001. Different aspects of green purchasing that are mentioned within the literature embrace the facilitation of recycling, reuse and resource reduction [50].

Green supply chain practices (GSCPs) normally include: investment recovery, ecological design, green purchasing, customer cooperation and internal environmental management [51] [52] [53] [54]. A number of studies started using GSCP adoption as an independent variable and performance as a dependent variable.

Adoption of GSCP is very relevant in developing nations where pollution is more severe resulting in health problems, death and disabilities of citizens on an annual basis [55].

\subsection{Green Purchasing}

The adoption of green purchasing is one among the usually accepted dimensions of Green Supply Chain Management (GSCM) practices that is in line with Lee [56] a buying enterprise with a green supply chain initiative will pay attention to green practices of their suppliers, particularly the small and medium-sized enterprises so that suppliers meet their environmental objectives.

\subsection{Eco Design Practice}

The importance of eco-design was identified by Buyukozkan and Cifci [57] where they revealed that nearly eighty percent (80\%) of product connected impacts on the environment can be influenced during design. Eco-design practices fall into two main classes-product-related design and packaging-related design. With reference to product design, Min and Galle [19] advised that cost-saving opportunities at the start of the supply chain tend to be larger which buying enterprises must actively look for opportunities to utilize recycled and reused parts.

\section{SMEs and Green Supply Chain Adoption}

Industrialization in developing nations is getting a high priority given the requirement for structural transformation from small-scale agriculture to manufacturing as a way to achieve comprehensive and pro-poor growth [55]. However, industrial enterprises, at least, to begin with, need to use large amounts of energy resources that themselves cause pollution and environmental degradation [58]. In order to address the problems mentioned above, three objectives were 
set that primarily focus on the influence of five GSCPs-Green Supply chain Practices (green purchasing, eco-design, investment recovery, internal environmental management and customer cooperation) on environmental performance; the second objective looks at the influence of GSCPs on economic advantages, while the third objective looks at the influence of GSCPs on economic costs [59].

As per Vijayvargy et al. [60], medium-sized enterprises have adopted GSCM practices identical to large scale enterprises, with three exceptions: existing environmental management systems, support from mid-level and top management and supplier evaluation for environmental practice. It was found that GSCM adoption causes equal enhancements in operational performance for each small and medium-sized enterprise.

SMEs always lack human resources [61]. For example, hiring an expert to initiate Restriction of Hazardous Substances (RoHS) compliance becomes an impediment to initiate Effluent Management System (EMSs) [62] [63]. Kim [64] compared the project management maturity levels between SMEs and Large enterprises in Korea. The results of his study indicated differences in various project management capabilities at different enterprises of different size and scale. Due to lack of human resources and internal innovation capability, SMEs experience difficulties in achieving satisfactory performance in their projects (i.e. implementing quality management (QMS) or Supply Chain Management (SCM) systems) variety of SMEs are struggling with implementing new needs of their buying enterprises primarily due to lack of knowledge, expertise, and financial and human resources. SMEs typically have inadequate proactive environmental strategy, environmental awareness, and environmental management techniques [65] [66]. They're typically ineffective in coping with environmental management issues. Thus, these SME suppliers will hinder the progress of customer enterprises' GSCM practices [67].

\section{Hypothesis Development}

There exist very few studies examining the relationships between GSCPs and performance that embrace more than one green practice and mix each environmental and economic performance outcomes, together with economic costs and advantages. Some studies found positive relationships between practice and performance [33] [36] [53], while some found negative relationships [24] while some found no relationship at all [1]. In our view, these inconsistencies arise from many reasons which are different from method considerations and it can be safely assumed that the distinction is primarily in contexts in which the research is conducted like national laws, business type and market conditions.

Klassen [68] and Preuss [69] argue for integrating environmental issues into the thought of SCM. Handfield et al. [70] recommend that environmental sustainability efforts be integrated throughout the value chain. Linton et al. [71] assert that the main focus of environmental management has moved from the enterprise level to the supply chain level. 
Whether going "green" really pays has been investigated at intervals with conclusive results [33] [37] [72]. Seuring [73] queries whether or not the adoption of environmental sustainability ends up in a win-win scenario or environmental and economic tradeoffs for the supply chain partners.

As the enterprises creating up a supply chain become tuned in to customer demands for products and services provided without damaging the environment, managers can take crucial decisions that support the integration and coordination of GSCM practices throughout the supply chain [74] [75]. Supply chains and enterprises will gain competitive advantage by being the first to adopt environmental sustainability and implement GSCM practices [70] [76] [77].

Environmental and economic performance is balanced by the enterprises facing regulative, competitive and community pressures [78]. Environmental sustainability is a vital concern for going green and most enterprises are adopting this as a deliberate strategy [79]. Such adoption practices end up in greater advantages that additionally affect customers and suppliers. Environmental legislation is one of the prime issues for manufacturers in a global economy [80].

Businesses are driven to embrace GSCM techniques that ultimately "confer both a positive net present value (NPV) and environmental benefits" [81]. That is, they're going to attempt to attenuate value further as maximize profit via sustainable measures.

GSCM practices were at first guided by one objective, i.e. environmental performance. However, in recent years enterprises have accomplished that this single objective cannot offer sustainability. Thus, responding to calls from academics which were long pending, enterprises have progressively begun to adopt more comprehensive performance frameworks, like the triple bottom line (TBL) [82] [83] [84] [85] [86]. Adopting a similar approach, Carter and Rogers [87] outlined Sustainable Supply Chain Management (SSCM) as a common region defined by three intersecting circles representing financial, social and environmental performance.

Analysis in earlier literature is characterized by conflicting findings on the influence of every Green Supply Chain Performance (GSCP) on environmental performance, variations that may be supported the context or nature of the particular practice [88]. In China, Zhu et al. [89] indicated that solely internal environmental management practices absolutely and considerably influence environmental performance, green purchasing features a negative impact on the environmental performance while remaining practices have no influence. On the contrary, in Thailand, Laosirihongthong et al. [1] found that green purchasing absolutely influenced environmental performance, and it is the sole practice of significance. In the USA, Green et al. [76] found that green purchasing has no important influence; but, eco-design, investment recovery and customer cooperation considerably and absolutely influence environmental performance.

Given the discussion above, it is evident that the very nature of GSCPs leads to different influences on environmental performance. This influence has unique 
advantages and importance at different process stages. For example, green purchasing differs from alternative practices at two stages: product specification and supplier choice wherever environmental problems are thought of [90]. Conversely, eco-design happens at every stage across the product life cycle.

Thus we propose (Figure 1):

$\mathrm{H} 1$ - Green purchasing directly impacts SMEs firm performance.

H2-Green Purchasing directly impacts Environment performance.

H3-Eco design directly impacts SMEs firm performance.

H4-Eco design directly impacts Environment performance.

\section{Research Methodology}

Data was collected using a pre-tested questionnaire from owners/managers from different Industry Associations and clusters in the SMEs domain in South India. The total sample size was 382 , of which 374 were usable, resulting in a response rate of around $97 \%$, which is regarded as satisfactory for a survey of this type (Table 1) [91].

\section{Data Analysis and Results}

Table 2 below presents the Descriptive analysis of SMEs identified for this study. 492 SME Enterprises participated. The sample consisted of 171(45.6\%), Electronics 87(23.2\%), Information and Communication 81 (21.6\%) and Pharmaceutical and medical services 35(9.6).

In the following recommendation of Anderson and Gerbing [92], a two-step approach for data analysis was taken up. In the first step, a measurement model was used to assess the validity and reliability of the measures. In the second step, structural model was used to test the proposed hypotheses.

\subsection{Measurement Model: Reliability and Validity}

The measurement model indicated an acceptable model-fit of the data $\left(\chi^{2}=204.739\right.$,

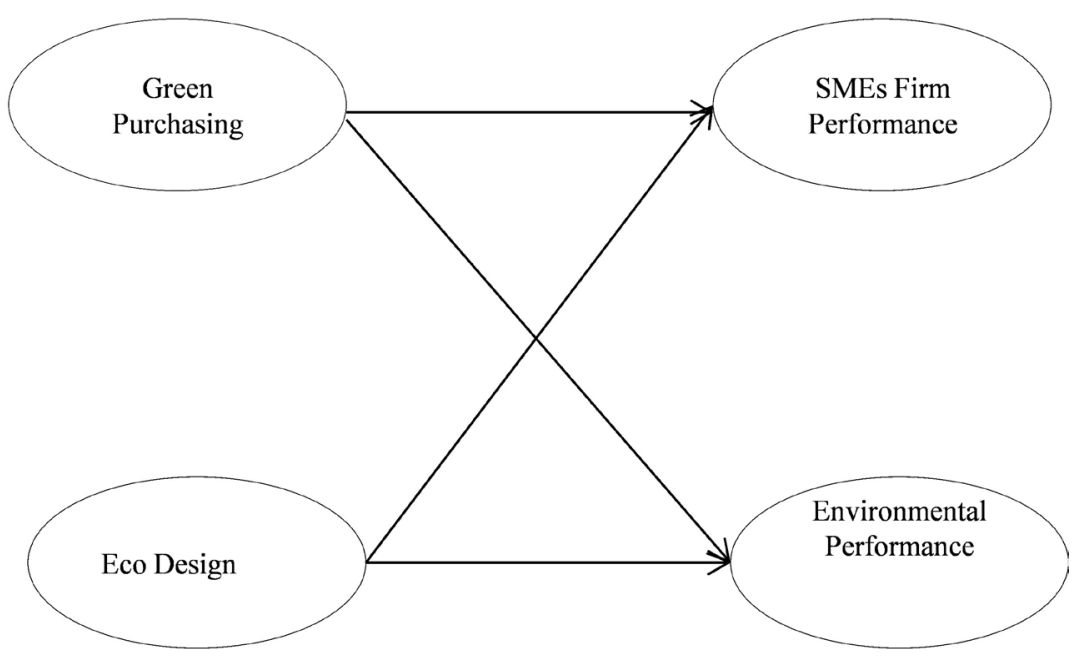

Figure 1. Proposed research model. 
Table 1. Measurement instruments.

\begin{tabular}{|c|c|}
\hline Construct & Item \\
\hline \multirow{4}{*}{$\begin{array}{l}\text { Green purchasing (Zhu et al., } \\
\text { 2008a) }\end{array}$} & Eco labeling of products. \\
\hline & Cooperation with suppliers for environmental objectives. \\
\hline & Environmental audit of suppliers' internal management. \\
\hline & Second-tier supplier environmentally friendly practice evaluation. \\
\hline \multirow[t]{3}{*}{ Eco-design (Zhu et al., 2008a) } & Design of products for reduced consumption of material/energy. \\
\hline & $\begin{array}{l}\text { Design of products for reuse, recycle, recovery of material and/or } \\
\text { component parts. }\end{array}$ \\
\hline & $\begin{array}{l}\text { Design of products to avoid or reduce use of hazardous products } \\
\text { and/or their manufacturing process. }\end{array}$ \\
\hline \multirow{5}{*}{$\begin{array}{l}\text { SMEs performance } \\
\text { (Sadiku-dushi et al., 2019) }\end{array}$} & My firm is usually satisfied with sale growth. \\
\hline & My firm is usually satisfied with market share growth. \\
\hline & My firm is usually satisfied with return on sales. \\
\hline & My firm is usually satisfied with net profit margins. \\
\hline & My firm is usually satisfied with gross profit margins. \\
\hline \multirow{5}{*}{$\begin{array}{l}\text { Environmental performance } \\
\text { (Zhu et al., 2008a) }\end{array}$} & Reduction of air emissions. \\
\hline & Reduction of effluent waste. \\
\hline & Reduction of solid wastes. \\
\hline & Decrease in consumption for hazardous/harmful/toxic materials. \\
\hline & Decrease in frequency for environmental accidents. \\
\hline
\end{tabular}

Table 2. Descriptive analysis.

\begin{tabular}{ccc}
\hline Type of Industry & Count & $\%$ \\
\hline Manufacturing & 171 & 45.6 \\
Electronics & 87 & 23.2 \\
Information and communication & 81 & 21.6 \\
Pharmaceutical and medical services & 35 & 9.6 \\
\hline
\end{tabular}

$d f=115 ; \chi^{2} / d f=1.7890 ;$ GFI $=0.944 ;$ AGFI $=0.925 ;$ TLI $=0.973 ;$ IFI $=0.977 ;$ $\mathrm{NFI}=0.949$; and RMR $=0.039$ ) [92]. In addition, all the indicators loaded significantly on the latent constructs. The values of the fit indices indicate a reasonable fit for the measurement model with data [93].

For the assessment of scale reliability, we have estimated the Cronbach alpha ( $\alpha$ ) value. Hair et al. [94] have emphasized that the reliability coefficient above 0.70 demonstrates adequate reliability. As shown in Table 3 below, all constructs have adequate reliability coefficients of greater than 0.70 . Thus, these four constructs hold good reliability coefficients (see Table 3 ). While Cronbach alpha is an estimate of construct reliability, Fornell and Larcker [95] have emphasized the reliability of each measurement item (indicator). Squared multiple correlations (SMC) is a measure to estimate indicator reliability. As mentioned in Table 3, 
Table 3. Reliability of items and constructs.

\begin{tabular}{|c|c|c|c|c|c|c|}
\hline Construct & Item & $\lambda$ & SMC & $\alpha$ & $\mathrm{CR}$ & AVE \\
\hline \multirow[t]{5}{*}{ Green purchasing } & V1 & 0.755 & 0.57 & 0.809 & 0.80 & 0.33 \\
\hline & $\mathrm{V} 2$ & 0.741 & 0.55 & & & \\
\hline & V3 & 0.632 & 0.40 & & & \\
\hline & $\mathrm{V} 4$ & 0.675 & 0.46 & & & \\
\hline & V5 & 0.564 & 0.32 & & & \\
\hline \multirow[t]{3}{*}{ Eco-design } & V1 & 0.906 & 0.82 & 0.75 & 0.96 & 0.44 \\
\hline & V2 & 0.985 & 0.97 & & & \\
\hline & V3 & 0.929 & 0.86 & & & \\
\hline \multirow[t]{5}{*}{ SMEs firm performance } & V1 & 0.9 & 0.81 & 0.936 & 0.88 & 0.76 \\
\hline & $\mathrm{V} 2$ & 0.762 & 0.58 & & & \\
\hline & V3 & 0.729 & 0.53 & & & \\
\hline & V4 & 0.74 & 0.55 & & & \\
\hline & V5 & 0.744 & 0.55 & & & \\
\hline \multirow[t]{5}{*}{ Environment performance } & V1 & 0.83 & 0.69 & 0.72 & 0.66 & 0.64 \\
\hline & V2 & 0.11 & 0.001 & & & \\
\hline & V3 & 0.5 & 0.25 & & & \\
\hline & V4 & 0.98 & 0.96 & & & \\
\hline & V5 & 0.004 & 0.00 & & & \\
\hline
\end{tabular}

Note (abbreviation): S.D. $=$ Standard Deviation, $\lambda=$ Standardized Factor Loading, SMC = Squared Multiple Correlation, $\mathrm{CR}=$ Composite Reliability, $\alpha=$ Cronbach Alpha, AVE = Average Variance Explained.

all SMC values are also greater than the suggested cut-off of 0.30 [96].

\subsection{Measurement: Reliability of Items and Constructs}

\subsection{Convergent Validity}

Convergent validity is defined as the degree to which items of measurement instrument correlate with items in the measurement instrument that are intended to measure the same construct. Hair et al. [94] suggested three criteria to ensure convergent validity: standardized factor loading of each individual indicator should be greater than 0.50 , the average variance explained value for each construct should be greater than 0.50 , and composite reliability (CR) value for each construct should be greater than 0.70. As shown in Table 3 above, identified factor structure (i.e. the measurement model) satisfies all three requirements. Therefore, this measurement model shows adequate convergent validity

\subsection{Discriminant Validity}

Discriminant validity was assessed by comparing the Average Variance Explained (AVE) with the corresponding inter-construct squared correlation estimates [95]. As shown in Table 3 above, the AVE values of all the factors are 
greater than the inter-construct correlations, which support the discriminant validity of the constructs. Thus, the measurement model has adequate reliability and construct validity.

\subsection{Structural Model: Estimation of Research Hypotheses}

Given the acceptable convergent validity and discriminant validity, the estimation of structural relationships then constitutes an assessment of hypothesized theoretical relationships. The structural model also fitted well with $\left(\chi^{2}=204.739\right.$, $d f=115 ; \chi^{2} / d f=1.7890 ; \mathrm{GFI}=0.944 ; \mathrm{AGFI}=0.925 ; \mathrm{TLI}=0.973 ; \mathrm{IFI}=0.977$;FI $=0.949$; and RMR $=0.039)$ Thus, all model fit indices met the acceptable threshold value of indices for model fit suggested by Anderson and Gerbing [92].

\section{Results and Discussion}

The results of the study (Table 4) indicate that green purchasing impacts firm performance (H1: $\beta=0.389, \mathrm{p}<0.001)$. This result validates earlier research by Kumar et al. [97], which says that GSCM practices provide the potential for cost savings, improved efficiency, attracting new suppliers and customers and improves brand reputation. This study also supports the relationship between green purchasing and environmental performance $(\mathrm{H} 2: \beta=0.071, \mathrm{p}<0.01)$ which validates results of previous studies which says that the processes that reduce waste and cut costs not only improve financial performance but can also improve environmental performance [98] [99]. Another result of this study indicates that that eco design impacts positively firm performance (H3: $\beta=0.389$, $\mathrm{p}<0.001$, this finding is validated in the research by Koh et al. [100], which indicates that eco-product design implies effective use of materials and waste reduction. Reduction of waste can lead to lowered costs for the organization and better use of materials can positively impact performance while eco-designed products can lead to improved brand image also. Eco design doses not impact significantly to environmental performance ( $\mathrm{H} 4: \beta=-0.15, \mathrm{p}=0.368)$.

\section{Discussion and Managerial Application}

Increased business activity the world over poses a threat to the environment in terms of environmental emissions, discarded packaging materials, scrapped material and other forms of industrial pollution [101]. In order to tackle environmental degradation many organizations began looking for ways and means to

Table 4. Results of hypothesis testing.

\begin{tabular}{|c|c|c|c|c|}
\hline Hypothesis & Hypothesized Relationship & $\begin{array}{c}\text { Path } \\
\text { Coefficient }\end{array}$ & p-Value & Result \\
\hline $\mathrm{H} 1$ & Green purchasing $\rightarrow$ SMEs performance & 0.389 & $<0.000$ & Supported \\
\hline $\mathrm{H} 2$ & Green purchasing $\rightarrow$ environmental performance & 0.071 & 0.096 & Supported \\
\hline H3 & Eco-design $\rightarrow$ SMEs performance & 0.062 & 0.030 & Supported \\
\hline $\mathrm{H} 4$ & Eco-design $\rightarrow$ environmental performance & -0.015 & 0.368 & Not supported \\
\hline
\end{tabular}


reduce the ill effects. GSCM was one such solution. GSCM as an innovative environmental activity that aims to minimize or eliminate wastage along the supply chain such as product design, material sourcing and selection, manufacturing process, delivery of final product and end of life management of the product. As the term indicates GSCM is an offshoot of Supply chain management. Intense competition pushed firms into pursuing environmentally responsible activities that had social and ethical dimensions. The usefulness of pursuing GSCM primarily reflects on explicit outcomes such as firm and environmental performance. An effort is made in this study to assess the impact of green purchasing and eco design on environmental and SME firm performance. Studies in the past were directed at large scale enterprises. Relatively fewer studies exist on small and medium enterprises in India which are considered "engines of growth" and contribute to the nation's economic growth. As of January 2019, there existed more than 63 million MSMEs, which accounted for $45 \%$ of industrial production, $30.5 \%$ of services sector and employed close to 110 million people. The share of MSME related products in the country exports was 48.56\% during 2017-18. (Ministry of MSME) [102]. Given the strategic importance of this sector it is imperative that its growth is accompanied by responsible policy frameworks aimed at industry growth with environmental sustainability. Ministry of Micro, Small and Medium Enterprises (MoMSME) in India launched a scheme to boost the idea of GSCM called ZED (Zero Defect-Zero Effect) on 31st July, 2017. The major idea is to promote the minimum wastage and minimum environmental impact in the SME's and making them capable to be the part of the GSCM to boost the export of India. To motivate the entrepreneurs, Govt. have also given certain subsidies under this scheme, e.g. Rs.25 Lakhs for setting up new Effluent Treatment Plant (ETP), new Technolgy, etc. Even Govt. gives 50\% loan concession and Rs 10 Lakhs for ZED certifications and handholding purposes.

The results of the empirical study indicate support for the hypothesized relationships. Green purchasing practices had a positive impact on SME firm as well as environmental performance. Eco-design has a positive impact on SME firm performance but not environmental performance. Reasons for lack of support need further enquiry. We assume some reasons behind the lack of support. In reality, GSCM and performance are inextricably related SCM concepts. At the macro level we observe strong relationships between green practices and performance but when the analysis gets granular to more specific aspects of supply chain practices such as eco design involving collaboration with suppliers in designing green products and adopting environmental practices into processes we observe that these areas have not been thoroughly researched upon. Further understanding of ground-level realities, spreading the coverage of research to other industries/sectors might provide a way to understand the weakness in this linkage.

\section{Limitations and Future Scope of Study}

The above study was conducted in a very specific context with nearly $45 \%$ of 
responses taken from SMEs in the manufacturing sector. For future studies, we propose the study can be expanded to include more variables such as Leadership, Organizational culture, financial strength, business diversity, location specific economies, etc. to name a few and understand their influence of GSCM on firm and environmental performance. More SME sectors can be included in studies with a focus on organizations that are directly contributing to carbon emissions and global warming.

GSCM practices are here to stay and industry, particularly MSMEs in developing countries such as India must understand the importance of such Green practices. Supply chains can look at innovative practices with taking the help of technology and collaborate with other parties in the supply chain to deliver quality products and services. Impediments will, however, continue to exist. The future of business to a large extent depends on the future of our environment and as such businesses need to understand this vital area of and pursue environmentally sustainable practices to stay competitive and relevant. The government should perform its role as a catalyst and ensure that MSMEs get the required impetus in this endeavor.

\section{Conflicts of Interest}

The authors declare no conflicts of interest regarding the publication of this paper.

\section{References}

[1] Laosirihongthong, T., Adebanjo, D. and Choon Tan, K. (2013) Green Supply Chain Management Practices and Performance. Industrial Management \& Data Systems, 113, 1088-1109. https://doi.org/10.1108/IMDS-04-2013-0164

[2] Namagembe, S., Sridharan, R. and Ryan, S. (2016) Green Supply Chain Management Practice Adoption in Ugandan SME Manufacturing Firms: The Role of Entrepreneurial Orientation. World Journal of Science, Technology and Sustainable Development, 13, 154-173. https://doi.org/10.1108/WJSTSD-01-2016-0003

[3] Puppim de Oliveira, J.A. and Jabbour, C.J.C. (2017) Environmental Management, Climate Change, CSR, and Governance in Clusters of Small Firms in Developing Countries: Toward an Integrated Analytical Framework. Business \& Society, 56, 130-151. https://doi.org/10.1177/0007650315575470

[4] Zeković, Z., Cvetanović, A., Pavlić, B., Švarc-Gajić, J. and Radojković, M. (2014) Optimization of the Polyphenolics Extraction from Chamomile Ligulate Flowers Using Response Surface Methodology. International Journal of Plant Research, 4, 43-50. https://doi.org/10.5937/savteh1501054Z

[5] Zobel, T. (2007) The "Pros" and "Cons" of Joint EMS and Group Certification: A Swedish Case Study. Corporate Social Responsibility and Environmental Management, 14, 152-166. https://doi.org/10.1002/csr.125

[6] Sarkis, J., Gonzalez-Torre, P. and Adenso-Diaz, B. (2010) Stakeholder Pressure and the Adoption of Environmental Practices: The Mediating Effect of Training. Journal of Operations Management, 28, 163-176. https://doi.org/10.1016/j.jom.2009.10.001

[7] Zhu, Q., Sarkis, J. and Lai, K.H. (2013) Institutional-Based Antecedents and Performance Outcomes of Internal and External Green Supply Chain Management 
Practices. Journal of Purchasing and Supply Management, 19, 106-117. https://doi.org/10.1016/j.pursup.2012.12.001

[8] Tamyez, P.F., Nor, N.M. and Nasir, S.J.A. (2015) The Adoption of Green Manufacturing Practices in Furniture Firms. In: The Malaysia-Japan Model on Technology Partnership, Springer, Tokyo, 377-384.

https://doi.org/10.1007/978-4-431-54439-5_38

[9] Blackman, A. (2010) Alternative Pollution Control Policies in Developing Countries. Review of Environmental Economics and Policy, 4, 234-253. https://doi.org/10.1093/reep/req005

[10] Ling, C.H. and Khor, M. (2002) International Environmental Governance: Some Issues from a Developing Country Perspective.

[11] Najam, A. (2005) Developing Countries and Global Environmental Governance: From Contestation to Participation to Engagement. International Environmental Agreements: Politics, Law and Economics, 5, 303-321. https://doi.org/10.1007/s10784-005-3807-6

[12] Coyle, J.J., Thomchick, E.A. and Ruamsook, K. (2015) Environmentally Sustainable Supply Chain Management: An Evolutionary Framework. In: Marketing Dynamism \& Sustainability: Things Change, Things Stay the Same..., Springer, Cham, 365-374. https://doi.org/10.1007/978-3-319-10912-1_129

[13] Esty, D., Esty, D.C. and Simmons, P.J. (2011) The Green to Gold Business Playbook: How to Implement Sustainability Practices for Bottom-Line Results in Every Business Function. John Wiley \& Sons, Hoboken.

[14] Smith, N., Halton, A. and Strachan, J. (2014) Transitioning to a Green Economy: Political Economy of Approaches in Small States. Commonwealth Secretariat, London.

[15] Aneyrao, T. and Ahemad, M. (2014) Green Supply Chain Management Practices by Indian Automobile Manufacturers: A Critical Review. Discovery, 26, 54-57.

[16] Cognizant, P. (2008) Creating a Green Supply Chain Information Technology as an Enabler for a Green Supply Chain.

[17] Zhang, X., Ma, X. and Wang, Y. (2012) Entrepreneurial Orientation, Social Capital, and the Internationalization of SMEs: Evidence from China. Thunderbird International Business Review, 54, 195-210. https://doi.org/10.1002/tie.21451

[18] Sarkis, J. (2003) A Strategic Decision Framework for Green Supply Chain Management. Journal of Cleaner Production, 11, 397-409. https://doi.org/10.1016/S0959-6526(02)00062-8

[19] Brammer, S. and Walker, H. (2011) Sustainable Procurement in the Public Sector: An International Comparative Study. International Journal of Operations \& Production Management, 31, 452-476. https://doi.org/10.1108/01443571111119551

[20] Min, H. and Galle, W.P. (2001) Green Purchasing Practices of US Firms. International Journal of Operations \& Production Management, 21, 1222-1238. https://doi.org/10.1108/EUM0000000005923

[21] Roehrich, J., Grosvold, J. and Hoejmose, S. (2014) Reputational Risks and Sustainable Supply Chain Management: Decision Making under Bounded Rationality. International Journal of Operations \& Production Management, 34, 695-719. https://doi.org/10.1108/IJOPM-10-2012-0449

[22] Sarkis, J., Meade, L.M. and Presley, A.R. (2012) Incorporating Sustainability into Contractor Evaluation and Team Formation in the Built Environment. Journal of Cleaner Production, 31, 40-53. https://doi.org/10.1016/j.jclepro.2012.02.029 
[23] Vachon, S. and Klassen, R.D. (2008) Environmental Management and Manufacturing Performance: The Role of Collaboration in the Supply Chain. International Journal of Production Economics, 111, 299-315. https://doi.org/10.1016/j.ijpe.2006.11.030

[24] Roehrich, J.K., Hoejmose, S.U. and Overland, V. (2017) Driving Green Supply Chain Management Performance through Supplier Selection and Value Internalisation: A Self-Determination Theory Perspective. International Journal of Operations \& Production Management, 37, 489-509. https://doi.org/10.1108/IJOPM-09-2015-0566

[25] Govindan, K., Rajendran, S., Sarkis, J. and Murugesan, P. (2015) Multi Criteria Decision Making Approaches for Green Supplier Evaluation and Selection: A Literature Review. Journal of Cleaner Production, 98, 66-83. https://doi.org/10.1016/j.jclepro.2013.06.046

[26] Eltayeb, T.K., Zailani, S. and Ramayah, T. (2011) Green Supply Chain Initiatives among Certified Companies in Malaysia and Environmental Sustainability: Investigating the Outcomes. Resources, Conservation and Recycling, 55, 495-506. https://doi.org/10.1016/j.resconrec.2010.09.003

[27] Hanim Mohamad Zailani, S., Eltayeb, T.K., Hsu, C.C. and Choon Tan, K. (2012) The Impact of External Institutional Drivers and Internal Strategy on Environmental Performance. International Journal of Operations \& Production Management, 32, 721-745. https://doi.org/10.1108/01443571211230943

[28] Bowen, F.E., Cousins, P.D., Lamming, R.C. and Farukt, A.C. (2001) The Role of Supply Management Capabilities in Green Supply. Production and Operations Management, 10, 174-189. https://doi.org/10.1111/j.1937-5956.2001.tb00077.x

[29] Seuring, S. (2011) Supply Chain Management for Sustainable Products-Insights from Research Applying Mixed Methodologies. Business Strategy and the Environment, 20, 471-484. https://doi.org/10.1002/bse.702

[30] Tachizawa, E.M., Gimenez, C. and Sierra, V. (2015) Green Supply Chain Management Approaches: Drivers and Performance Implications. International Journal of Operations \& Production Management, 35, 1546-1566. https://doi.org/10.1108/IJOPM-01-2015-0023

[31] Pagell, M. and Wu, Z. (2009) Building a More Complete Theory of Sustainable Supply Chain Management Using Case Studies of 10 Exemplars. Journal of Supply Chain Management, 45, 37-56. https://doi.org/10.1111/j.1745-493X.2009.03162.x

[32] Lamming, R. and Hampson, J. (1996) The Environment as a Supply Chain Management Issue. British Journal of Management, 7, S45-S62. https://doi.org/10.1111/j.1467-8551.1996.tb00147.x

[33] Wiengarten, F., Pagell, M. and Fynes, B. (2012) Supply Chain Environmental Investments in Dynamic Industries: Comparing Investment and Performance Differences with Static Industries. International Journal of Production Economics, 135, 541-551. https://doi.org/10.1016/j.ijpe.2011.03.011

[34] Zhu, Q., Sarkis, J. and Lai, K.H. (2008) Confirmation of a Measurement Model for Green Supply Chain Management Practices Implementation. International Journal of Production Economics, 111, 261-273. https://doi.org/10.1016/j.ijpe.2006.11.029

[35] Rao, P. and Holt, D. (2005) Do Green Supply Chains Lead to Competitiveness and Economic Performance? International Journal of Operations \& Production Management, 25, 898-916. https://doi.org/10.1108/01443570510613956

[36] Green Jr., K.W., Zelbst, P.J., Meacham, J. and Bhadauria, V.S. (2012) Green Supply Chain Management Practices: Impact on Performance. Supply Chain Management. 
An International Journal, 17, 290-305. https://doi.org/10.1108/13598541211227126

[37] Green, K.W., Whitten, D. and Inman, R.A. (2008) The Impact of Logistics Performance on Organizational Performance in a Supply Chain Context. Supply Chain Management: An International Journal, 13, 317-327. https://doi.org/10.1108/13598540810882206

[38] Srivastava, S.K. (2007) Green Supply-Chain Management: A State-of-the-Art Literature Review. International Journal of Management Reviews, 9, 53-80. https://doi.org/10.1111/j.1468-2370.2007.00202.x

[39] Zhu, Q. and Sarkis, J. (2004) Relationships between Operational Practices and Performance among Early Adopters of Green Supply Chain Management Practices in Chinese Manufacturing Enterprises. Journal of Operations Management, 22, 265-289. https://doi.org/10.1016/j.jom.2004.01.005

[40] Ahi, P. and Searcy, C. (2013) A Comparative Literature Analysis of Definitions for Green and Sustainable Supply Chain Management. Journal of Cleaner Production, 52, 329-341. https://doi.org/10.1016/j.jclepro.2013.02.018

[41] Gilbert, S. (2001) Greening Supply Chain: Enhancing Competitiveness through Green Productivity. Asian Productivity Organization, Tokyo, Vol. 16, 1-6.

[42] Zhu, Q. and Sarkis, J. (2007) The Moderating Effects of Institutional Pressures on Emergent Green Supply Chain Practices and Performance. International Journal of Production Research, 45, 4333-4355. https://doi.org/10.1080/00207540701440345

[43] Hsu, C.W. and Hu, A.H. (2008) Green Supply Chain Management in the Electronic Industry. International Journal of Environmental Science \& Technology, 5, 205-216. https://doi.org/10.1007/BF03326014

[44] Delmas, M. and Toffel, M.W. (2004) Stakeholders and Environmental Management Practices: An Institutional Framework. Business Strategy and the Environment, 13, 209-222. https://doi.org/10.1002/bse.409

[45] Rivera, J. (2004) Institutional Pressures and Voluntary Environmental Behavior in Developing Countries: Evidence from the Costa Rican Hotel Industry. Society and Natural Resources, 17, 779-797. https://doi.org/10.1080/08941920490493783

[46] Narasimhan, R. and Carter, J.C. (1998) Environmental Supply Chain Management, Research Monograph. Center for Advanced Purchasing Studies, Tempe.

[47] Carter, J.R., Smeltzer, L.R. and Narasimhan, R. (2000) Human Resource Management within Purchasing Management: Its Relationship to Total Quality Management Success. Journal of Supply Chain Management, 36, 52-62. https://doi.org/10.1111/j.1745-493X.2000.tb00077.x

[48] Heras-Saizarbitoria, I., Arana Landín, G. and Molina-Azorín, J.F. (2011) Do Drivers Matter for the Benefits of ISO 14001? International Journal of Operations \& Production Management, 31, 192-216. https://doi.org/10.1108/01443571111104764

[49] Vachon, S. (2007) Green Supply Chain Practices and the Selection of Environmental Technologies. International Journal of Production Research, 45, 4357-4379. https://doi.org/10.1080/00207540701440303

[50] Diabat, A. and Govindan, K. (2011) An Analysis of the Drivers Affecting the Implementation of Green Supply Chain Management. Resources, Conservation and Recycling, 55, 659-667. https://doi.org/10.1016/j.resconrec.2010.12.002

[51] Zsidisin, G.A. and Hendrick, T.E. (1998) Purchasing's Involvement in Environmental Issues: A Multi-Country Perspective. Industrial Management \& Data Systems, 98, 313-320. https://doi.org/10.1108/02635579810241773

[52] Zhu, Q., Sarkis, J. and Geng, Y. (2005) Green Supply Chain Management in China: 
Pressures, Practices and Performance. International Journal of Operations \& Production Management, 25, 449-468. https://doi.org/10.1108/01443570510593148

[53] Chien, M.K. and Shih, L.H. (2007) An Empirical Study of the Implementation of Green Supply Chain Management Practices in the Electrical and Electronic Industry and Their Relation to Organizational Performances. International Journal of Environmental Science and Technology, 4, 383-394.

[54] Zhu, Q., Sarkis, J. and Lai, K.H. (2008) Green Supply Chain Management Implications for "Closing the Loop". Transportation Research Part E: Logistics and Transportation Review, 44, 1-18. https://doi.org/10.1016/j.tre.2006.06.003

[55] Omoju, O. (2014) Environmental Pollution Is Inevitable in Developing Countries. Breaking Media.

[56] Lee, S.Y. (2008) Drivers for the Participation of Small and Medium-Sized Suppliers in Green Supply Chain Initiatives. Supply Chain Management. An International Journal, 13, 185-198. https://doi.org/10.1108/13598540810871235

[57] Büyüközkan, G. and Çifçi, G. (2012) Evaluation of the Green Supply Chain Management Practices: A Fuzzy ANP Approach. Production Planning \& Control, 23, 405-418. https://doi.org/10.1080/09537287.2011.561814

[58] Bruce, N. and Ellis, G.M. (1993) Environmental Taxes and Policies for Developing Countries. World Bank Publications, Washington DC, 1177.

[59] Namagembe, S., Ryan, S. and Sridharan, R. (2019) Green Supply Chain Practice Adoption and Firm Performance: Manufacturing SMEs in Uganda. Management of Environmental Quality: An International Journal, 30, 5-35.

https://doi.org/10.1108/MEQ-10-2017-0119

[60] Vijayvargy, L., Thakkar, J. and Agarwal, G. (2017) Green Supply Chain Management Practices and Performance: The Role of Firm-Size for Emerging Economies. Journal of Manufacturing Technology Management, 28, 299-323. https://doi.org/10.1108/JMTM-09-2016-0123

[61] Lee, S.M., Tae Kim, S. and Choi, D. (2012) Green Supply Chain Management and Organizational Performance. Industrial Management \& Data Systems, 112, 1148-1180. https://doi.org/10.1108/02635571211264609

[62] Lee, K.H. (2009) Why and How to Adopt Green Management into Business Organizations? The Case Study of Korean SMEs in Manufacturing Industry. Management Decision, 47, 1101-1121. https://doi.org/10.1108/00251740910978322

[63] Adams, J.H., Khoja, F.M. and Kauffman, R. (2012) An Empirical Study of Buyer-Supplier Relationships within Small Business Organizations. Journal of Small Business Management, 50, 20-40. https://doi.org/10.1111/j.1540-627X.2011.00342.x

[64] Kim, S. (2011) Adopting Systematic Project Management Methods for Productivity Improvement: Comparison of the Project Management Maturity Levels between SMEs and Large Firms. Asia Pacific Journal of Small Business, 33, 5-12.

[65] Shearlock, C., Hooper, P. and Millington, S. (2000) Environmental Improvement in Small and Medium-Sized Enterprises. Greener Management International, 30, 50-60. https://doi.org/10.9774/GLEAF.3062.2000.su.00006

[66] Sarkis, J. and Dijkshoorn, J. (2007) Relationships between Solid Waste Management Performance and Environmental Practice Adoption in Welsh Small and $\mathrm{Me}$ dium-Sized Enterprises (SMEs). International Journal of Production Research, 45, 4989-5015. https://doi.org/10.1080/00207540600690529

[67] Lee, S.Y. and Klassen, R.D. (2008) Drivers and Enablers That Foster Environmental Management Capabilities in Small- and Medium-Sized Suppliers in Supply Chains. 
Production and Operations Management, 17, 573-586. https://doi.org/10.3401/poms.1080.0063

[68] Klassen, R.D. and McLaughlin, C.P. (1993) TQM and Environmental Excellence in Manufacturing. Industrial Management \& Data Systems, 93, 14-22. https://doi.org/10.1108/02635579310040924

[69] Preuss, L. (2002) Green Light for Greener Supply. Business Ethics: A European Review, 11, 308-317. https://doi.org/10.1111/1467-8608.00290

[70] Handfield, R.B., Walton, S.V., Seegers, L.K. and Melnyk, S.A. (1997) Green' Value Chain Practices in the Furniture Industry. Journal of Operations Management, 15, 293-315. https://doi.org/10.1016/S0272-6963(97)00004-1

[71] Linton, J.D., Klassen, R. and Jayaraman, V. (2007) Sustainable Supply Chains: An Introduction. Journal of Operations Management, 25, 1075-1082. https://doi.org/10.1016/j.jom.2007.01.012

[72] King, A.A. and Lenox, M.J. (2001) Lean and Green? An Empirical Examination of the Relationship between Lean Production and Environmental Performance. Production and Operations Management, 10, 244-256. https://doi.org/10.1111/j.1937-5956.2001.tb00373.x

[73] Seuring, S.A. (2001) Green Supply Chain Costing Joint Cost Management in the Polyester Linings Supply Chain. Greener Management International, No. 33, 71-80. https://doi.org/10.9774/GLEAF.3062.2001.sp.00008

[74] Vachon, S. and Klassen, R.D. (2007) Supply Chain Management and Environmental Technologies: The Role of Integration. International Journal of Production Research, 45, 401-423. https://doi.org/10.1080/00207540600597781

[75] Vachon, S. and Klassen, R.D. (2006) Extending Green Practices across the Supply Chain: The Impact of Upstream and Downstream Integration. International Journal of Operations \& Production Management, 26, 795-821. https://doi.org/10.1108/01443570610672248

[76] Sen, S. (2009) Linking Green Supply Chain Management and Shareholder Value Creation. IUP Journal of Supply Chain Management, 6, 95-109.

[77] Barratt, M. and Oke, A. (2007) Antecedents of Supply Chain Visibility in Retail Supply Chains: A Resource-Based Theory Perspective. Journal of Operations Management, 25, 1217-1233. https://doi.org/10.1016/j.jom.2007.01.003

[78] Schulze, L. and Li, L. (2010) Identification of Decision-Making Modes towards Green Supply Chain. In: Proceedings of the 6th CIRP-Sponsored International Conference on Digital Enterprise Technology, Springer, Berlin, Heidelberg, 1421-1433. https://doi.org/10.1007/978-3-642-10430-5_108

[79] Malviya, R.K. and Kant, R. (2015) Green Supply Chain Management (GSCM): A Structured Literature Review and Research Implications. Benchmarking: An International Journal, 22, 1360-1394. https://doi.org/10.1108/BIJ-01-2014-0001

[80] Ninlawan, C., Seksan, P., Tossapol, K. and Pilada, W. (2010) The Implementation of Green Supply Chain Management Practices in Electronics Industry. In: Proceedings of the International Multiconference of Engineers and Computer Scientists, Vol. 3, IMECS, Hong Kong, 17-19.

[81] Industry Canada (2013) Logistics and Supply Chain Management Green Supply Chain Management: Retail Chains and Consumer Product Goods-A Canadian Perspective.

[82] Awaysheh, A. and Klassen, R.D. (2010) The Impact of Supply Chain Structure on the Use of Supplier Socially Responsible Practices. International Journal of Opera- 
tions \& Production Management, 30, 1246-1268.

https://doi.org/10.1108/01443571011094253

[83] Paulraj, A. and De Jong, P. (2011) The Effect of ISO 14001 Certification Announcements on Stock Performance. International Journal of Operations \& Production Management, 31, 765-788. https://doi.org/10.1108/01443571111144841

[84] Gimenez, C., Sierra, V. and Rodon, J. (2012) Sustainable Operations: Their Impact on the Triple Bottom Line. International Journal of Production Economics, 140, 149-159. https://doi.org/10.1016/j.ijpe.2012.01.035

[85] De Giovanni, P. (2012) Do Internal and External Environmental Management Contribute to the Triple Bottom Line? International Journal of Operations \& Production Management, 32, 265-290. https://doi.org/10.1108/01443571211212574

[86] Hollos, D., Blome, C. and Foerstl, K. (2012) Does Sustainable Supplier Co-Operation Affect Performance? Examining Implications for the Triple Bottom Line. International Journal of Production Research, 50, 2968-2986. https://doi.org/10.1080/00207543.2011.582184

[87] Carter, C.R. and Rogers, D.S. (2008) A Framework of Sustainable Supply Chain Management: Moving toward New Theory. International Journal of Physical Distribution \& Logistics Management, 38, 360-387. https://doi.org/10.1108/09600030810882816

[88] Dubey, R., Gunasekaran, A. and Papadopoulos, T. (2017) Green Supply Chain Management: Theoretical Framework and Further Research Directions. Benchmarking: An International Journal, 24, 184-218. https://doi.org/10.1108/BIJ-01-2016-0011

[89] Zhu, Q., Sarkis, J. and Lai, K.H. (2007) Green Supply Chain Management: Pressures, Practices and Performance within the Chinese Automobile Industry. Journal of Cleaner Production, 15, 1041-1052. https://doi.org/10.1016/j.jclepro.2006.05.021

[90] Blengini, G.A., Busto, M., Fantoni, M. and Fino, D. (2012) Eco-Efficient Waste Glass Recycling: Integrated Waste Management and Green Product Development through LCA. Waste Management, 32, 1000-1008. https://doi.org/10.1016/j.wasman.2011.10.018

[91] Malhotra, N.K. (2011) Basic Marketing Research. Pearson, Boston.

[92] Anderson, J.C. and Gerbing, D.W. (1988), Structural Equation Modeling in Practice: A Review and Recommended Two-Step Approach, Psychological Bulletin, 103, 411-423. https://doi.org/10.1037//0033-2909.103.3.411

[93] Byrne, B.M. (2001) Structural Equation Modeling: Perspectives on the Present and the Future. International Journal of Testing, 1, 327-334. https://doi.org/10.1207/S15327574IJT013\&4_11

[94] Hair, J.F., Anderson, R.E., Tatham, R.L. and Black, W.C. (2012) Multivariate Data Analysis. 7th Edition, Prentice Hall, Englewood Cliffs.

[95] Fornell, C. and Larcker, D. (1981) Evaluating Structure Models and Unobservable Variable and Measurement Errors. Journal of Marketing Research, 18, 39-50. https://doi.org/10.1177/002224378101800104

[96] Bagozzi, R.P. and Yi, Y. (1988) On the Evaluation of Structural Equation Models. Journal of the Academy of Marketing Science, 16, 74-94. https://doi.org/10.1007/BF02723327

[97] Kumar, S., Teichman, S. and Timpernagel, T. (2012) A Green Supply Chain Is a Requirement for Profitability. International Journal of Production Research, 50, 1278-1296. https://doi.org/10.1080/00207543.2011.571924 
[98] Curkovic, S., Melnyk, S.A., Handfield, R.B. and Calantone, R. (2000) Investigating the Linkage between Total Quality Management and Environmentally Responsible Manufacturing. IEEE Transactions on Engineering Management, 47, 444-464. https://doi.org/10.1109/17.895340

[99] Wu, Z. and Pagell, M. (2011) Balancing Priorities: Decision-Making in Sustainable Supply Chain Management. Journal of Operations Management, 29, 577-590. https://doi.org/10.1016/j.jom.2010.10.001

[100] Koh, S.C., Gunasekaran, A. and Tseng, C.S. (2012) Cross-Tier Ripple and Indirect Effects of Directives WEEE and RoHS on Greening a Supply Chain. International Journal of Production Economics, 140, 305-317. https://doi.org/10.1016/j.ijpe.2011.05.008

[101] Chin, T.A., Tat, H.H. and Sulaiman, Z. (2015) Green Supply Chain Management, Environmental Collaboration and Sustainability Performance. Procedia CIRP, 26, 695-699. https://doi.org/10.1016/j.procir.2014.07.035

[102] Ministry of Small and Medium Enterprises, Government of India. https://msme.gov.in/desk-js-sme-jan-2019 